\title{
Pengaruh Sistem Informasi Manajemen Dan Pelayanan Publik Terhadap Kinerja Pegawai Penerima Pendapatan Dikantor Sistem Administrasi Manunggal Satu Atap (SAMSAT)Aek Kanopan
}

\author{
Morapahu Pardomuan Siregar \\ Universitas Muhammadiyah Sumatera Utara, Medan, Indonesia
}

Corresponding Author: morapahusiregar@gmail.com

\begin{abstract}
Government organizations are large organizations that serve and accommodate all levels of society with applicable laws and regulations. Therefore, government organizations must have reliable and productive human resources by trying to improve the performance of employees. Performance is the result of work that can be achieved by employees or groups of employees in an organization, in accordance with their respective authorities and responsibilities in an effort to achieve organizational goals. Good performance is influenced by two things, namely management information systems and good public services. This Research Aims To Know The Influence Of Management Information System And Public Service To The Performance Of The Employee Revenue Receipt At The One-Stop Manunggal Administration System Office (Samsat) Aek Kanopan. This research approach uses an associative approach. The data collection method used a questionnaire/questionnaire which was distributed to all employees receiving income at the SAMSAT Aek Kanopan office which is located at J1. Class of 66 Aek Kanopan, Kualuh Hulu District, North Labuhanbatu Regency. And the research sample was 36 employees. The research sample and Data Analysis Techniques in this study are the classical assumption test which includes the normality test, multicollinearity test, and heteroscedasticity test. In Data Analysis Techniques include multiple linear regression test, hypothesis testing, test the coefficient of determination $\left(\mathrm{R}^{2}\right)$. The results showed that partially the Management Information System had a positive and significant effect on employee performance, public services had a positive and significant effect on employee performance, and simultaneously the management information system and public services had an effect on the performance of the employee revenue receipts at the one-stop single-stop administrative system office ( Samsat) Aek Kanopan.
\end{abstract}

Keywords Management Information System, Public Service, Employee Performance

\section{PENDAHULUAN}

Organisasi pemerintah merupakan organisasi besar yang melayani dan mewadahi seluruh lapisan masyarakat dengan undang-undang dan hukum yang berlaku. Maka dari itu, organisasi pemerintah harus memiliki sumber daya manusia yang handal dan produktif dengan berupaya meningkatkan 
kinerja para pegawai. Kinerja merupakan hasil kerja yang dapat dicapai oleh pegawai atau kelompok pegawai dalam suatu organisasi, sesuai dengan wewenang dan tanggung jawab masing-masing dalam upaya mencapai tujuan organisasi. Kinerja yang baik dipengaruhi dua hal yaitu sistem informasi manajemen dan pelayanan publik yang baik.

Kinerja organisasi sering menjadi tidak maksimal karena beberapa sebab yaitu, kurangnya dukungan sumber daya manusia yang berkualitas, mempromosikan jabatan yang tidak tepat, tidak melihat pada tingkat atau level pendidikan pegawai, pengalaman kerja, agar para pegawai itu termotivasi untuk meningkatkan kinerjanya, akan tetapi justru dalam bekerja muncul kekwatiran dan cenderung untuk meninggalkan pekerjaan. Pegawai yang memiliki kemampuan dan sikap professional dalam bekerja sangat mungkin dapat mencapai hasil kerja yang di harapkan serta semakin tinggi maka kinerja kerja pegawai akan semakin tinggi, akan tetapi kenyataan yang terjadi dilapangan malah sebaliknya, berbagai kendala yang dihadapi para pegawai sehingga kinerja pegawai di Kantor Samsat Aek Kanopan menurun.

Informasi berasal dari suatu data atau fakta yang harus diolah terlebih dahulu yang memerlukan sistem pengolahan informasi yang disebut Sistem Informasi Manajemen. Informasi yang dihasilkan diperoleh dari data-data yang telah diolah dan disimpan untuk sewaktu-waktu dipergunakan. Data-data yang diperoleh telah melewati tahapan pengolahan data yang kemudian menjadi informasi ini umumnya menggunakan sistem informasi yang berbasis komputer (computer based information system).

Semakin besar sebuah organisasi maka semakin banyak data yang harus diolah serta semakin luas jaringan informasi yang akan dikelola. Pengolahan data telah menjadi bagian penting dalam Sistem Informasi Manajemen yang akan memperngaruhi setiap aktivitas organisasi. Data yang diolah menjadi informasi akan dimanfaatkan dalam membuat keputusan, menunjang tugas rutin, evaluasi, serta kebutuhan untuk bersaing. Setiap organisasi saat ini membutuhkan pegawai yang berpengetahuan (knowledge worker). Pegawaiyang mempunyai ilmu yang baik dalam bidangnya, akan memudahkan dalam pencapaian tujuan organisasi. Untuk itu diperlukan semangat dan keinginan yang kuat dari dalam diri sendiri untuk meningkatkan kualitas dirinya untuk menghasilkan hasil kinerja yang baik.

Sistem Informasi Manajemen memiliki peran dan manfaat yang signifikan antara fasilitas pengolah data dengan pegawai sebagai user, dimana keterkaitan antara satu unit dengan unit lainnya akan saling terintegrasi dalam proses pengumpulan data, pemrosesan data, penyimpanan data, umpan balik data, serta pendistribusian data terhadap internal dan eksternal organisasi. Proses 
peningkatan kinerja pegawai dalam satu organisasi dapat dilihat dari fasilitas yang mendukung para pegawai dalam mengolah data-data yang berupa informasi demi tercapainya tujuan organisasi. Dimana sistem informasi akan sangat dibutuhkan sebagai sarana organisasi dalam menyampaikan keputusan yang telah diambil dari data-data yang diproses.

Selain pegawai, organisasi juga harus menyadari bahwa informasi adalah kebutuhan mendasar dan merupakan sumber daya penting yang harus dikelola dengan baik. Dengan demikian, dengan adanya teknologi dan sistem informasi akan memudahkan dalam memperoleh informasi serta memepercepat organisasi dalam menyebarkan informasi agar terhindar dari kesalahankesalahan yang tak terduga akibat keterlambatan informasi.

Administrasi kepemerintahan yang dilaksanakan oleh instansi Pemerintah di Pusat, di Daerah, dan lingkungan Badan Usaha Milik Negara atau Badan Usaha Milik Daerah menggunakan istilah konsepsi pelayanan kepada masyarakat dengan sebutan pelayanan publik (public service) yang mencakup berbagai pelayanan administrasi. Pemerintah dituntut untuk menghasilkan barang dan jasa (pelayanan) yang ekonomis, efektif, efisien dan akuntabel kepada seluruh masyarakat yang membutuhkan. Pemberian pelayanan publik olehaparatur pemerintah kepada rakyat sebenarnya merupakan implikasi dari fungsi aparat negara sebagai pelayan rakyat. Dalam kondisi masyarakat yang semakin kritis, birokrasi publik dituntut harus dapat mengubah posisi dan peran dalam memberikan pelayanan publik. Dari yang suka mengatur dan memerintah, berubah menjadi suka melayani, dari yang suka menggunakan pendekatan kekuasaan berubah menjadi suka menolong tanpa diskriminatif. Pelayanan publik dapat diartikan sebagai pemberian layanan (melayani) keperluan seseorang atau masyarakat yang mempunyai kepentingan pada organisasi itu sesuai dengan aturan pokok dan tata cara yang telah ditetapkan. Hal ini memberikan pemahaman bahwa segala sesuatu yang berkaitan dengan pelayanan, hendaknya harus dilaksanakan dengan sebaik mungkin agar masyarakat yang menerima pelayanan itu merasa puas atas pelayanan yangdiberikan.

Berdasarkan hasil wawancara terhadap bebarapa orang pegawai pada Kantor Sistem Administrasi Manunggal Satu Atap (SAMSAT) Aek Kanopan bahwa yang menjadi permasalahan selama ini sehingga kinerja pegawai menurun yang diakibatkan oleh sebagian pegawai yang kurang memaksimalkan kinerjanya dalam bekerja dan seharusnya pihak organisasi harus tanggap dalam mengolah informasi yang masuk agar dapat diproses dengan cepat. Seperti kejadian dimana ada masyarakat atau warga yang melakukan protes terhadap Kantor SAMSAT Aek Kanopan kurangnya 
pemberian informasi kepada masyarakat yang menjadi wajib pajak sehingga masyarakatmengeluh dengan sistem informasi yang diberikan.

Berdasarkan hasil diskusi dengan beberapa orang warga atau masyarakat yang mengatakan bahwa pelayanan yang diberikan para pegawai yang kurang tanggap dalammembantu dan memberikan pelayanan yang cepat dan tanggap terhadap masyarakat, kurangnya kemampuan handal dan bertanggungjawab para pegawai pada kantor Sistem Administrasi Manunggal Satu Atap (Samsat) Aek Kanopan, kurangnya sikap sopan dan ramah, kurangnya kemampuan dalam memberikan perhatian yang bersifat individual atau pribadi kepada orang lain.

Kantor Sistem Administrasi Manunggal Satu Atap (Samsat) Aek Kanopan yang merupakan perwakilan disalah satu kabupaten/kota yang ada di Sumatera Utara yang disebut UPT (Unit Pelaksana Tugas). Kantor bersama SAMSAT Aek Kanopan merupakan perwakilan kantor SAMSAT di daerah Kabupaten Labuhanbatu Utara (Labura) Provinsi Sumatera Utara dan merupakan tempat para wajib pajak kendaraan bermotor di Kabupaten Labuhan Batu Utara melakukan pembayaran pajak kendaraan bermotornya. Selain itu dari tahun ke tahun jumlah kendaraan bermotor semakin meningkat, sehingga menyebabkan jumlah wajib pajak kendaraan bermotor semakin meningkat pula.

Dengan demikian, penulis melihat bahwa fenomena yang terjadi yaitu sebagian pegawai yang kurang memaksimalkan kinerjanya dalam bekerja hal ini terlihat dari kurangnya pemberian informasi kepada masyarakat yang menjadi wajib pajak sehingga masyarakat mengeluh dengan sistem informasi yang diberikan, selain itu kurangnya kemampuan handal dan bertanggungjawab para pegawai pada kantor Sistem Administrasi Manunggal Satu Atap (Samsat) Aek Kanopan dan kurangnya sikap sopan dan ramah, kurangnya kemampuan dalam memberikan perhatian yang bersifat individual atau pribadi kepada orang lain, sehingga dengan adanya fenomena ini peneliti mencoba meneliti permasalahan ini dengan mengangkat judul : "Pengaruh Sistem Informasi Manajemen Dan Pelayanan Publik Terhadap Kinerja Pegawai Penerima Pendapatan Dikantor Sistem Administrasi Manunggal Satu Atap (SAMSAT) Aek Kanopan".

\section{METODE PENELITIAN}

Pada peneletian ini peneliti menggunakan pendekatan asosiatif. Menurut Sugiyono (2016) pendekatan asosiatif yaitu penelitian yang bertujuan untuk mengetahui hubungan antara dua variabel atau lebih dan menggunakan perhitungan angka-angka yang nantinya akandipergunakan untuk mengambil 
suatu keputusan di dalam memecahkan masalah dan data yang diperoleh dianalisis dengan menggunakan teori yang telah berlaku secara umum.

Metode pengumpulan data menggunakan kuisioner/angket yang disebarkan kepada seluruh pegawai penerima pendapatan di kantor SAMSAT Aek Kanopan yang beralamat di Jl. Angkatan 66 Aek kanopan, Kecamatan Kualuh Hulu, Kabupaten Labuhanbatu Utara. Sampel penelitian sebanyak 36 orang pegawai. Teknik Analisis Data dalam penelitian ini yaitu uji asumsi klasik yang meliputi uji normalitas, uji multikolinearitas, dan uji heteroskedastisitas. Dalam Teknik Analisis Data meliputi uji regresi linear berganda, uji hipotesis, uji koefisien determinasi $\left(\mathrm{R}^{2}\right)$.

\section{HASIL DAN PEMBAHASAN}

\section{Hasil Penelitian}

Teknik pengumpulan data yang telah dijelaskan pada bab sebelumnya, bahwa populasi penelitian adalah pegawai yang merupakan penerima pendapatan di Kantor Sistem Administrasi Manunggal Satu Atap (SAMSAT) Aek Kanopan yang beralamat di Jl. Angkatan No.66, Aek Kanopan, Kualuh Hulu, Kabupaten Labuhanbatu Utara, Sumatera Utara. Angket / kuisioner yang disebarkan kepada responden secara keseluruhan adalah 36 kuisioner, dan seluruh kuisioner tersebut memenuhi syarat dan telah diisi dan dilengkapi oleh responden.

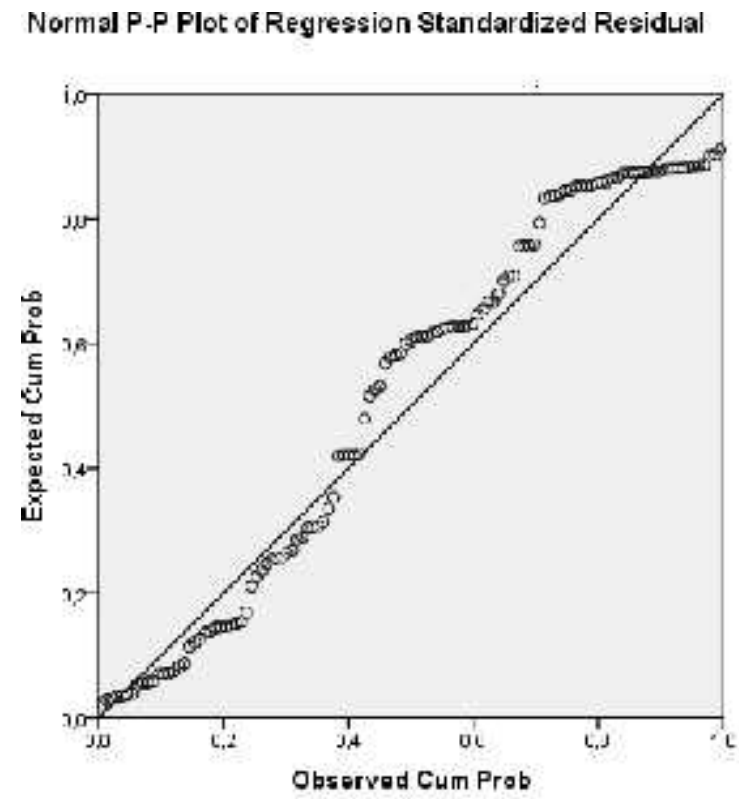

\section{Gambar 1. Uji Normalitas P-Plot}

Berdasarkan gambar di atas menunjukkan bahwa model regresi telah memenuhi asumsi yang telah dikemukakan sebelumnya dimana nilai Sistem Informasi Manajemen dan Pelayanan Publik dan Kinerja Pegawai Penerimaan 
Pendapatan telah terdistribusi normal karena masing-masing variabel memilki probabilitas lebih dari 0,05 (5\%). Nilai variabel yang memenuhi standar yang ditetapkan pada baris Asym.sig. (2-tailed) $=0,061(61 \%)$. Dari nilai tersebut dapat disimpulkan bahwa nilai Asym.sig (2-tailed) lebih besar dari 0,05 yang berarti variabel telah terdistribusi secara normal.

Pengujian multikolinearitas digunakan untuk menunjukkan apakah ada korelasi diantara variabel independen. Di dalam penelitian yang menggunakan teknik analisa regresi berganda antar variabel independen tidak boleh saling berkorelasi atau terjadi multikolinearitas.

Tabel 1. Hasil Pengujian Multikolinieritas

\begin{tabular}{|c|c|c|c|c|c|c|c|c|}
\hline \multirow{2}{*}{\multicolumn{2}{|c|}{ Model }} & \multicolumn{2}{|c|}{$\begin{array}{l}\text { Unstandardized } \\
\text { Coefficients }\end{array}$} & \multirow{2}{*}{$\begin{array}{c}\begin{array}{c}\text { Standardized } \\
\text { Coefficients }\end{array} \\
\text { Beta } \\
\end{array}$} & \multirow[b]{2}{*}{$\mathrm{t}$} & \multirow[b]{2}{*}{ Sig } & \multicolumn{2}{|c|}{$\begin{array}{l}\text { Collinearity } \\
\text { Statistics }\end{array}$} \\
\hline & & B & Std. Error & & & & Tolerance & VIF \\
\hline 1 & (Constant) & 18,190 & 4,346 & & 4,185 & , 000 & & \\
\hline & $\begin{array}{l}\text { Sistem } \\
\text { Informasi }\end{array}$ & ,272 & ,088 & ,075 & 1,811 & ,009 & 987 & 1,013 \\
\hline & $\begin{array}{l}\text { Manajemen } \\
\text { Pelayanan } \\
\text { Publik }\end{array}$ & 167 & 093 & ,066 & 1,719 & ,074 & 995 & 1,005 \\
\hline
\end{tabular}

Semua variabel Independen, masing-masing memiliki nilai VIF berada < 10. Demikian juga hasil nilai tolerance $>0.10$. maka dapat disimpulkan bahwa penelitian ini tidak terjadi multikolinearitas.

Uji heteroskedastisitas bertujuan untuk menguji apakah dalam satu model regresiterjadi ketidaksamaan varian residual dari satu pengamatan ke pengamatan yang lain. Model regresi yang baik adalah regresi yang tidak terdapat heteroskedastisitas, yaitu model regresi yang memiliki persamaan variance residual suatu periode pengamatan dengan periode pengamatan yang lain.

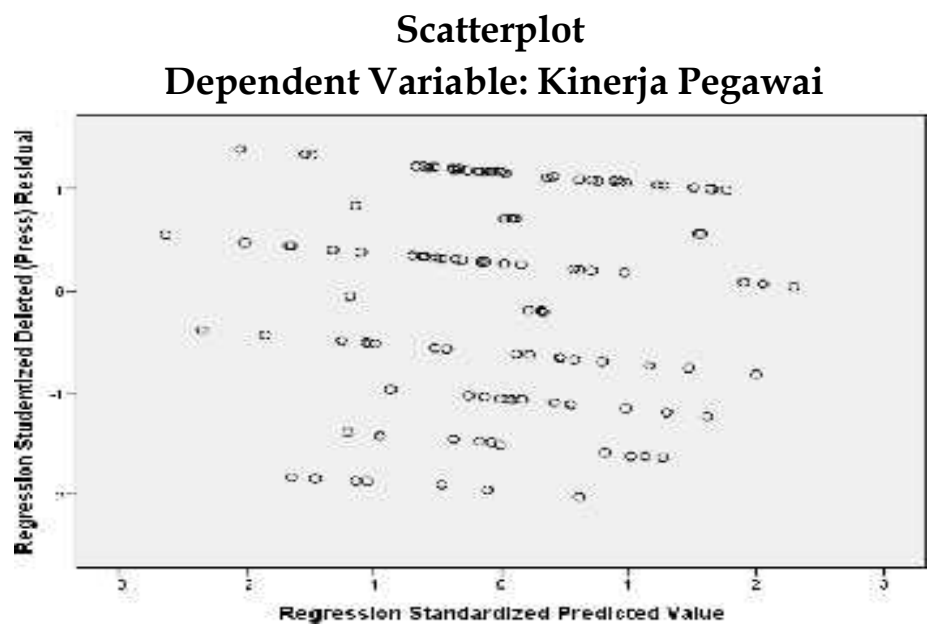

Gambar 2. Scatterplot 
Gambar di atas memperlihatkan titik-titik menyebar secara acak. Tidak membentuk pola yang jelas/teratur, tersebar secara baik di atas maupun dibawah angka 0 pada sumbu $Y$. Dengan demikian "tidak terjadi heteroskedastisitas" pada model regresi.

\section{Pembahasan}

\section{Pengaruh Sistem Informasi Manajemen Terhadap Kinerja Pegawai}

Berdasarkan hasil penelitian mengenai pengaruh antara Sistem Informasi Manajemen Terhadap Kinerja Pegawai Penerima Pendapatan di Kantor Sistem Administrasi Manunggal Satu Atap (SAMSAT) Aek Kanopan yang menyatakan thitung $>$ ttabel $=1,811>1,65$, artinya itu berada di luar daerah penerimaan Ha sehingga Ho diterima, hal ini dinyatakan bahwa Sistem Informasi Manajemen secara parsial berpengaruh positif dan signifikan terhadap Kinerja Pegawai Penerima Pendapatan di Kantor Sistem Administrasi Manunggal Satu Atap (SAMSAT) Aek Kanopan.

Penerapan Sistem Informasi Manajemen selain melakukan pengolahan sumber daya yang dimiliki organisasi yaitu informasi, diharapkan dapat memberikan nilai tambah dalam menjalankan tugas organisasi, yang mana nilai tambah tersebut dapat memberikan manfaat untuk organisasi dengan ditandai oleh tercapainya tujuan organisasi secara efektif dan efisien sesuai dengan apa yang telah direncanakan.

Sistem Informasi Manajemen diharapkan dapat membantu organisasi dalam menjalankan tugasnya dengan tercapainya kinerja pegawai yang ditandai tercapainya tujuan organisasi secara efektif dan efisien sesuai dengan apa yang telah direncanakan dan ditetapkan sebelumnya. Azhar Susanto (2017:68) dalam bukunya Sistem Informasi Manajemen Konsep dan Pengembangannya yang mengemukakan pengertian Sistem Informasi Manajemen, yaitu : Sistem Informasi Manajemen merupakan kumpulan dari sub-sub sistem yang saling berhubungan satu sama lain dan bekerja sama secara harmonis untuk mencapai satu tujuan yaitu mengolah data menjadi informasi yang diperlukan oleh manajemen dalam proses pengambilan keputusan saat melaksanakan fungsinya.

Sedangkan kinerja pegawai berarti hasil kerja secara kualitas dan kuantitas yang dicapai oleh seorang pegawai dalam melaksanakan pekerjaannya sesuai dengan tanggungjawab yang diberikan oleh pimpinan. Kinerja merupakan hasil yang diperoleh pegawai berdasarkan kualitas atau mutu pekerjaan : sebaik apa yang harus dikerjakan, kriteriaini mengukur baik tidaknya pelaksanaan kegiatan, terutama dalam kaitannya dengan keluaran. Agus Dahrma (2016:149) dalam bukunya Manajemen Supervisi, 
memberikan penjelasan mengenai penilaian kinerja, sebagai berikut: Untuk dapat menilai kinerja karyawan secara objektif dan akurat adalah dengan mengukur tingkat kinerja karyawan. Pengukuran kinerja dapat juga berfungsi sebagai upaya mengumpulkan informasi yang dapat digunakan untuk mengarahkan upaya karyawan melalui serangkaian prioritas tertentu. Keterkaitan Sistem Informasi Manajemen dengan kinerja pegawai menyentuh berbagai aspek, keberadaan tiap level manajemen serta anggota organisasi yang terpadu dengan mesin dalam pelaksanaan kegiatan kinerja pegawai yang menyentuh tugas dan fungsi organisasi.

Dengan demikian dapat disimpulkan bahwa dengan adanya Sistem Informasi Manajemen dapat meningkatkan kinerja pegawai penerimaan pendapatan. hal ini sejalan dengan penelitian Jhon Hendrik (2016) dalam penelitiannya yang berjudul Pengaruh Sistem Informasi Manajemen Terhadap Kinerja Pegawai Pada Sekretariat Daerah Kabupaten Tanggamus yang menyatakan bahwa Sistem Informasi Manajemen mempunyai berpengaruh positif dan signifikan terhadap kinerja pegawai pada Sekretariat Daerah Kabupaten Tanggamus.

\section{Pengaruh Pelayanan Publik Terhadap Kinerja Pegawai}

Berdasarkan hasil penelitian mengenai pengaruh antara Pelayanan Publik Terhadap Kinerja Pegawai Penerima Pendapatan di Kantor Sistem Administrasi Manunggal Satu Atap (SAMSAT) Aek Kanopan yang menyatakan nilai thitung $>$ ttabel $=1,719>1,65$, artinya itu berada di luar daerah penerimaan Ha sehingga Ho diterima, hal ini dinyatakan bahwa Pelayanan Publik secara parsial berpengaruh positif dan signifikan terhadap Kinerja Pegawai Penerima Pendapatan di Kantor Sistem Administrasi Manunggal Satu Atap (SAMSAT) Aek Kanopan.

Membangun kepercayaan masyarakat atas pelayanan publik yang dilakukan penyelenggara pelayanan publik merupakan kegiatan yang harus dilakukan seiring dengan harapan masyarakat. Meskipun perangkat peraturan teknis bidang pelayanan publik terus dilaksanakan secara berkesinambungan dan menunjukkan perbaikan mutu pelayanan namun masih saja banyak keluhan dan kekecewaan masyarakat terhadap pelayanan yang diberikan oleh aparatur pemerintah.Pelayanan yang baik bagi masyarakat akan ditanggapi positif dengan dukungan atas program yang dijalankan pemerintah, sebaliknya pelayanan yang buruk akan memberi respon negatif yang menyebabkan penolakan terhadap pemerintah. Artinya disini terjadi hubungan langsung antara pelayanan publik yang dilakukan aparatur pemerintah terhadap kinerja pemerintah itu sendiri. 
Dalam memberikan pelayanan publik, instansi penyedia pelayanan publik harus memperhatikan asas akuntabilitas, transparansi, dan partisipasi publik (Mahmudi, 2010). Dengan demikian jika suatu daerah menerapkan ketiga asas tersebut secara bersamaan dan dengan baik, maka semakin baik pula kinerja organisasi layanan publik.

Dengan demikian dapat disimpulkan bahwa terdapat adanya hubungan yang signifikanantara Pelayanan Publik terhadap kinerja. hal ini sejalan dengan penelitian Sandani Nor (2019) dalam penelitiannya yang berjudul "Pengaruh Pelayanan Publik Trerhadap Kinerja Pegawai Dinas Kebersihan Dan Pertamanan Kota Samarinda", yang menyatakan bahwa Koefisien korelasi rank spearman yang diperoleh sebesar 0,33 atau t hitung sebesar 0,42 menunjukkan terdapat hubungan (asosiasi) yang signifikan antara Pelayanan Publik dengan Kinerja Pegawai. Pelayanan publik yang baik akan mendapat tanggapan posistif dari masyarakat sehingga akan mendorong peningkatan kinerja pegawai di lingkungan DinasKebersihan dan Pertamanan Kota Samarinda.

\section{Pengaruh Sistem Informasi Manajemen Dan Pelayanan Publik Terhadap Kinerja Pegawai}

Berdasarkan hasil penelitian mengenai pengaruh antara Sistem Informasi Manajemen Dan Pelayanan Publik terhadap Kinerja Pegawai Penerima Pendapatan di Kantor Sistem Administrasi Manunggal Satu Atap (SAMSAT) Aek Kanopan yang menyatakan Fhitung $=7,390>$ Ftabel 3,280 dengan nilai probabilitas yakni signifikasi sebesar 0,001 < 0.05, artinya itu berada di luar daerah penerimaan Ha sehingga Ho diterima, hal ini menyatakan bahwa Sistem Informasi Manajemen Dan Pelayanan Publik secara simultan berpengaruh positif dan signifikan terhadap kinerja pegawai Penerima Pendapatan di Kantor Sistem Administrasi Manunggal Satu Atap (SAMSAT) Aek Kanopan.

\section{KESIMPULAN}

1. Secara parsial Sistem Informasi Manajemen berpengaruh positif dan signifikan terhadap Kinerja Pegawai Penerima Pendapatan di Kantor Sistem Administrasi Manunggal Satu Atap (SAMSAT) Aek Kanopan.

2. Secara parsial Pelayanan Publik berpengaruh positif dan signifikan terhadap Kinerja Pegawai Penerima Pendapatan di Kantor Sistem Administrasi Manunggal Satu Atap(SAMSAT) Aek Kanopan.

3. Sistem Informasi Manajemen Dan Pelayanan Publik berpengaruh secara simultan terhadap Kinerja Pegawai Penerima Pendapatan di Kantor Sistem Administrasi Manunggal Satu Atap (SAMSAT) Aek Kanopan. 


\section{REFERENCES}

Agita, D. D. \& A. L. N. (2020). Pengaruh Kualitas Pelayanan, Kewajiban Moral, Dan Sanksi Perpajakan Terhadap Kepatuhan Wajib Pajak Hotel Di Kota Tegal No Title. Jurnal MONEX, 9(2).

Agus Arini, N. \& S. (2019). Pengaruh Kewajiban Moral, Pemahaman Peraturan Perpajakan, Kesadaran Membayar Pajak, Kualitas Pelayanan, Pemeriksaan Pajak, Kondisi Keuangan, Dan Sanksi Perpajakan Terhadap Kepatuhan Wajib Pajak Badan. Jurnal Eprints.Uad.Ac.Id, 1(1).

Anjani, D. N. \&, \& M.M.D, R. (2016). Studi Empiris Theory Of Planned Behavior Dan Pengaruh Kewajiban Moral Pada Perilaku Ketidakpatuhan Pajak Wajib Pajak Orang Pribadi. Jurnal Berkala Akuntansi Dan Keuangan Indonesia,1(2).

Aryandini, S. (2016). Pengaruh, Kewajiban Moral, Pemeriksaan Pajak, Dan Kondisi Keuangan Terhadap Kepatuhan Wajib Pajak Badan Untuk Usaha Hotel Yang Terdaftar Di Dinas Pendapatan Daerah Kota Pekanbaru. JOM Fekon, 3(1).

Azizah, I., Nengah, O., \& Farah, S. D. (2014). Analisis Efektivitasdan Kontribusipajak Daerah Sebagaisumber Pendapatan Asli Daerah Kota Batu (Studi Pada Dinaspendapatan Daerah Kota Batu Tahun 2009-2013. Jurnal Administrasi Bisnis, 15(1), 1-7.

Cahyanti, E.P., Wafirotin K.Z., Hartono, A. (2019). Pengaruh Kesadaran Kualitas Pelayanan, Kewajiban Moral, Pengetahuan Pajak, Dan Persepsi Sanksi Perpajakan Pada Kepatuhan Pembayaran Pajak Kendaraan Bermotor Di KabupatenPonorogo.ISOQUANT :JurnalEkonomi,ManajemenDanAkuntansi,3(1) Dahrani, Sari, M., Saragih, F., \& Jufrizen. (2021). Model Kepatuhan Wajib Pajak (Studi Pada Wajib Pajak Yang Melakukan Usaha Di Kota Medan). Jurnal Akuntansi Dan Pajak, 21(02).

Daulay, R., \& Putri, R. E. (2018). Analisis Faktor-Faktor Psikologis Terhadap Keputusan Pembelian Kosmetik Wardah Di Kota Medan. Prosiding Konferensi Nasional Ke-8,1-6.

Dewi, P.A \& Jati, I. . (2019). Pengaruh Kesadaran WP, Kualitas Pelayanan, Kewajiban Moral, Sanksi, Pemeriksaan Pada Kepatuhan WP Hotel BAPENDA Badung. E-Jurnal Akuntansi Universitas Udayana,28(2).

Elia, M. (2007). Kajian Empiris Tentang Kepatuhan Wajib Pajak Badan Di Perusahaan Industri Pengolahan Di Surabaya. Simposium Nasional Akuntansi X.

Fitria, D. (2017). Pengaruh Kesadaran Wajib Pajak, Pengetahuan Dan Pemahaman Perpajakan Terhadap Kepatuhan Wajib Pajak. Journal of Applied Business And Economic (JABE), 4(1). 
Gani, A. I. A. A., Hidayat, K., \& Pamungkas, M. G. W. E. N. (2016). Pengaruh Kepatuhan Wajib Pajak Hotel Dan Restoran Terhadap Penerimaan Pajak Daerah (Studi Pada Dinas Pendapatan Daerah Kota Malang). Jurnal Perpajakan (JEJAK),8(1-7).

Ghozali. (2016). Aplikasi Analisis Multivariete Dengan Program IBM SPSS. Badan Penerbit Universitas Diponegoro.

Hirani, E., \& Silalahi, A. D. (2020). Pengaruh Kewajiban Moral dan Akuntanbilitas Pelayanan Publik Terhadap Kepatuhan Wajib Pajak Bumi dan Bangunan Pada Badan Pajak dan Retribusi Daerah Kota Medan. Journal of Trends Economics and Accounting Research, 1(1),23-28.

Horota, Parson., Riani, I.A.P., dan Marbun, R. . (n.d.). Peningkatan Pendapatan Asli Daerah Dalam Rangka Otonomi Daerah Melalui Potensi Pajak Dan Retribusi daerah Di Kabupaten Jayapura. Jurnal Keuda, 2(1).

I M.A.D \& Jati, I. ketut P. (2017). Analisis Faktor-Faktor Yang Mempengaruhi Kepatuhan Wajib Pajak Kendaraan Bermotor Di Kantor Bersama Samsat Tabanan. E-JurnalAkuntansi Universitas Udayana, 18(1).

Ilhamsyah, R., Endang, M. G. W., \& Dewantara, R. Y. (2016). Pengaruh Pemahaman Dan Pengetahuan Wajib Pajak Tentang Peraturan Perpajakan, Kesadaran Wajib Pajak, Kualitas pelayanan, Dan Sanksi Perpajakan Terhadap Kepatuhan Wajib Pajak Kendaraan Bermotor (Studi Samsat Kota Malang). Jurnal Perpajakan (JEJAK), 8(1).

Kawengian, P. ., Sabijono, H., \& Budiarso, N. S. (2017). Pengaruh Lingkungan Wajib Pajak, Kontrol Keperilakuan Yang Dipersepsikan Dan Kewajiban Moral Terhadap Kepatuhan Wajib Pajak Orang Pribadi Di Kelurahan Paal Dua Manado. Jurnal Riset Akuntansi Going Concern, 12(2),480-494.

Kemala, W. (2015). Pengaruh Kesadaran Wajib Pajak, Pengetahuan Pajak, Sikap Wajib Pajak Dan Reformasi Administrasi Perpajakan Terhadap Kepatuhan Wajib Pajak Kendaraan Bermotor. Jurnal JOM. FEKON, 2(1),1-15.

Krisolita, B. (2018). Pengaruh Kesadaran Wajib Pajak, Pengetahuan Wajib Pajak, Dan Kualitas Pelayanan Perpajakan Terhadap Kepatuhan Wajib Pajak Hotel Di Kota Batu. Jurnal Ilmiah Mahasiswa FEB Universitas Brawijaya, 7(1). Layata, S., \& Setiawan, P. E. (2014). Pengaruh Kewajiban Moral, Kualitas Pelayanan, Pemeriksaan Pajak Dan Sanksi Perpajakan Pada Kepatuhan Wajib Pajak Badan. E-Jurnal Akuntansi Universitas Udayana, 9(2), 540-556.

Nabila, Z.D \& Dra. Isroah, M. S. (2019). Pengaruh Kewajiban Moral Dan Lingkungan Sosial Terhadap Kepatuhan Wajib Pajak Orang Pribadi Pengusahaan. Jurnal Nominal, VII(I). 
Parera, A. M. W., \& Erawati, T. (2017). Pengaruh Kesadaran Wajib Pajak, Sanksi Perpajakan, Pengetahuan Perpajakan, Dan Pelayanan Fiskus Terhadap Kepatuhan Wajib Pajak Bumi Dan Bangunan. Jurnal Akuntansi, 5(1), 37-48.

Permatasari, I. (2016). Pengaruh Pendapatan Daerah terhadap Belanja Modal Pada KabupatenJawa Timur. Jurnal Ilmu Dan Riset Akuntansi, 5(1).

Pratiwi, I. G. A. M. A. M. A., \& Setiawan, P. E. (2014). Pengaruh Kesadaran Wajib Pajak, Kualitas Pelayanan, Kondisi Keuangan Perusahaan, Dan Persepsi Tentang Sanksi Perpajakan Pada Kepatuhan Wajib Pajak Reklame Di Dinas Pendapatan Kota Denpasar. Jurnal Akuntansi, 6(1),139153.

Prayitno, Sunarto dan Harjanto, R.(2017). Manajemen Komunikasi Pemasaran Terpadu:Integrated Marketing Communications Management. PT. RajaGrafindo Persada.

Putri, A. R. S \& Jati, I. K. (2013). Faktor-Faktor Yang Mempengaruhi Kepatuhan Wajib PajakDalam Membayar Pajak Kendaraan Bermotor Di Denpasar. EJurnal Akuntansi Universitas Udayana,2(3).

Putri1, A. R. S. \&, \&Jati, I. K. (2020). Faktor-Faktor Yang Mempengaruhi Kepatuhan Wajib Pajak Dalam Membayar Pajak Kendaraan Bermotor Di Denpasar. E- Jurnal AkuntansiUniversitas Udayana,30(6).

Rahmadika, L., Iskandar, N. S., \& Afifudin. (2020). Pengaruh Kualitas Pelayanan, Kewajiban Moral, Dan Sanksi Pajak Terhadap Kepatuhan Wajib Pajak Dalam Membayar Pajak Daerah. E-Jra, 09(04),63-75.

Sanjaya, I. P. A. P. (2014). Pengaruh kualitas pelayanan, kewajiban moral dan sanksi perpajakan pada kepatuhan wajib pajak dalam membayar pajak hotel. E-Jurnal Akuntansi Universitas Udayana, 7(1),207-222.

Siregar, D. L. (2017). Pengaruh Kesadaran Wajib Pajak Dan Sanksi Pajak Terhadap Kepatuhan Wajib Pajak Orang Pribadi Pada Kantor Pelayanan Pajak Pratama Batam. Journal Of Accounting Innovation,1(2).

Sista, N. putu A. (2019). Pengaruh Kesadaran Wajib Pajak, Kualitas Pelayanan Pajak, Kewajiban Moral, Dan Sanksi Pajak Terhadap Kepatuhan Wajib Pajak Kendaraan Bermotor Di Kantor Samsat Gianyar. Jurnal Sains, Akuntansi Dan Manajemen,1(1).

Stevanus Gomies, S. J., \& Pattiasina, V. (2011). Analisis Kontribusi Pajak Daerah dan Retribusi Daerah Terhadap Pendapatan Asli Daerah di Kabupaten Maluku Tenggara. Jurnal Widyamanggala, 13(2), 175-183.

Sugiyono. (2016). Metode Penelitian Kuantitatif, Kualitatif dan RED. PT Alfabeta. Suryani, \& Saleh, M. (2018). Pengaruh Kesadaran Wajib Pajak, Pemeriksaan pajak dan Ketegasan Sanksi Pajak terhadap Kepatuhan Pengusaha Hotel 
dalam Membayar Pajak Hotel. Jurnal Ilmiah Mahasiswa Ekonomi Akuntansi, 3(2), 298- 308.

Trisnawati, M., \& Sudirman, W. (2015). Analisis Faktor-Faktor Yang Mempengaruhi Kepatuhan Wajib Pajak Membayar Pajak Hotel , Pajak Restoran Dan Pajak Hiburan Di Kota Denpasar. E-Jurnal Akuntansi Universitas Udayana, 4(12), 975-1000.

Umboh, W.R, Tinangon, J.J, Afandi, D. (2020). Analisis Sistem Penerimaan Pajak Kendaraan Bermotor Di UPTD Samsat Manado. Jurnal Riset Akuntansi, 15(2).

Wahyudi, H. \&, \& Sanjaya, S. (2018). Efek Mediasi Kepatuhan Wajib Pajak Pada Pengaruh Pemahaman Dan Kesadaran Wajib Pajak terhadap Keberhasilan Penerimaan Pajak Penghasilan. Jurnal Kumpulan Penelitian Dan Pengabdian Dosen, 1(1).

Warliana, S., \& Arifin, S. B. (2016). Pengaruh Kesadaran Wajib Pajak dan Sanksi Pajak Terhadap Penerimaan Pajak di Kantor Pelayanan Pajak Pratama Medan Barat. Jurnal Riset Akuntansi \& Bisnis, 16(1).

Widari, B. E. (2016). Analisis Penerimaan Pajak Bumi Dan Bangunan Terhadap Pendapatan Daerah Pemerintah Kota Surabaya. Jurnal Ilmu Dan Riset Manajemen, 5(10), 1-17. 